\title{
1. Introduction: the living wage
}

\section{INTRODUCTION}

For the past decade a social movement with a goal of providing workers with a living wage has been growing in the US. Comprised of labour unions, religious groups and community organizations, the movement has focused on helping low-wage workers in local areas get higher wages through the use of political action and moral persuasion (Pollin and Luce, 2000: 1; Freeman, 2005: 14-15). The movement has made small gains in attaining its goal of a living wage, with success in about 100 municipal governments by 2003 and victories at some major universities (Luce, 2004: 33-5). In 2007, the state of Maryland implemented a living wage law that required contractors doing business with it to pay their workers a living wage of $\$ 11.30$ an hour in high-cost areas and $\$ 8.50$ an hour in rural areas.

Advocates for a living wage typically support it by arguing that it is necessary for 'economic justice' and a 'fair economy' (Pollin and Luce, 2000: title page and 1). This appeal for justness and fairness has long been a standard argument in favour of the living wage. The living wage movement began in the US in the 1870s and in 1906 one of its early advocates, Monsignor John Augustine Ryan, published an influential book, A Living Wage: Its Ethical and Economic Aspects. Ryan set forth his thesis as, 'The laborer's claim to a living wage is of the nature of a right' (Ryan, 1920: 3). $\mathrm{He}$ did not rely on economic arguments, feeling that moral value took precedence over economic value (Ryan, 1920: 68). More recently, Jerold L. Waltman has presented an expanded update of Ryan's work, The Case for the Living Wage, which he dedicates to Ryan. Waltman focuses on the political aspects of the living wage and justifies it on moral grounds rooted in religion (Waltman, 2004: 29-53).

\section{ECONOMISTS AND THE LIVING WAGE}

The typical economist today, however, would argue that justice, fairness, rights and dignity are not economic concepts and the movement for a living wage begs important questions of what and why. What is a living wage and why should we provide workers with one? In a free market economy, such 
an economist would say, wages represent a market estimation of what a worker adds to the production of goods and services that society wants. Under this value-added approach, workers paid low wages have low productivity. Paying them a living wage greater than their value-added involves a transfer of income from someone to low-paid workers. Who that someone should be and what implications the transfer of income will have on economic performance are issues that the typical economist would want answered before joining the movement for a living wage. Until those issues are resolved to their satisfaction, most economists today are not going to be members of the living wage movement.

In addition, these economists would argue, the market system rests on a structure of incentive. People in an economy should decide for themselves what productive activities to pursue to earn the best living possible. The quest for income draws those people into the most lucrative activity available to them in terms of the value they add to the economy. That income will enable them to purchase a range of goods and services from others in the economy. The standard of living itself then becomes an incentive for productive activity. A living wage would tamper with this incentive structure and upset the efficiency of a value-added economy. Given the importance economists place on efficiency, they would not support a living wage that undermines the incentive structure.

This lack of support for a living wage from economists, however, is a recent occurrence. We can see the how recent this opposition is through a glimpse at the history of the movement for a living wage. The movement began in the US in the 1870s and followed one that started a bit earlier in the UK (Pollin and Luce, 2000: 27). We can find evidence of its existence in the UK when, in 1894, The Economic Journal reported on 'A remarkable series of articles on "A Living Wage". . . in the Leeds Mercury' (Economic Journal, 1894: 365). By 1912, Philip Snowden, a Member of Parliament who would later become Chancellor of the Exchequer in the first Labour Party Government, had published a book, The Living Wage, an account of legislative efforts in the UK to secure a decent standard of living for workers. In Snowden's book as well as in Ryan's A Living Wage, the authors grappled with all the issues present-day advocates for a living wage face, such as how to define a living wage and what justification can be found to support it.

More important from the perspective of this book, a surprising part of this early living wage movement is that its members counted economists as supporters of the living wage. Ryan used the writings of John Stuart Mill and Alfred Marshall in support of his definition of a living wage (Ryan, 1920: 95-6). Similarly, in a chapter in his book titled 'The economy of high wages,' Snowden offered the following statement, 'From Adam Smith 
downwards economists have pointed out that higher wages made labour more efficient, and led to an increased output of work; larger in quantity and better in quality' (Snowden, 1912: 145). And in a book titled The Living Wage and the Law of Supply and Demand, published in 1895, Robert Blanchard pointed out that when opponents of a living wage said it was against a law of economics, they should be asked, 'In what book on political economy can that law be found?' Those opponents, he went on, 'will be unable to tell you' (quoted in Pollin and Luce, 2000: xxi). In his more recent book on the living wage, Waltman quotes Adam Smith several times as part of his case for a living wage (Waltman, 2004: 20 and 89).

This book is about the economists from Adam Smith downwards and what views they held regarding the living wage. Its objective is to make an important point. While the current movement for a living wage has gained a great deal of attention, economic thinkers have been concerned with the issue of a living wage for a long time, for as long as economics has been a topic of interest to social thinkers. We will see that even if we date the beginning of economics with the ideas of Adam Smith, earlier thinkers such as Plato, Aristotle and St Thomas Aquinas pondered the what, why and how of a living wage. Following Adam Smith, great thinkers in the history of economic thought continuously considered the negative consequences to society of paying workers low wages. The lack of concern for a living wage that can be found among economists today is a recent episode in the history of economic thought that started in the early twentieth century. This book will highlight how the ideas of the early economists contrast with the ideas of more recent economists, with the expectation that the lessons we can learn from the contrasting ideas of both the early and recent economists will help us to think more clearly about the issues surrounding whether workers should be paid a living wage. Its premise is that the great thinkers in the history of economic thought are still worth reading for the lessons we can gain from their keen general knowledge about the relationship between markets and the society that surrounds them.

In calling forth these lessons my intention is not to resolve the economic issues surrounding the current movement for a living wage. Robert Pollin and Stephanie Luce have covered this ground very well (Pollin and Luce, 2000), as has Waltman (Waltman, 2004: 127-47). Rather, I will review the ideas of many economic thinkers from Adam Smith downwards and focus on what lessons we can still learn from them. In anticipation of those lessons, in this introduction I will highlight three distinct arguments in favour of a living wage that the early economists developed in support of according workers a decent standard of living. Using the terminology of modern economics, I will contend in this book that the economists from Adam Smith downwards to the twentieth century supported the idea of a 
living wage based on the sustainability and capability of the labour force and the externality effect of not ensuring that sustainability and capability.

\section{SUSTAINABILITY}

The key approach to sustainability in modern economics dates from the publication of Garret Hardin's classic article, 'The tragedy of the commons' (Hardin, 1968). The tragedy of the commons takes into account the problem that arises when no one has an incentive to take care of common property. For example, to encourage students to reduce their driving on campus, my college once experimented with a 'free bike' system; bicycles were made available at various spots on campus and students could take one, ride to class, and leave it for another student to use. Within a week, all of the bikes were broken or gone. A more telling example is fishing in the ocean. Since no one owns the ocean or the fish in it making them 'free,' commercial fisherman may catch as many fish as they can as fast as they can, leading to over fishing and a depletion of the 'free' resource. The term used to describe the opposite of such depletion is sustainability, that is, how to ensure that the supply of a renewable resource is sustained.

At first glance it is hard to see how this approach could apply to labour. After all labour is not a free good and workers 'own' their labour. Fish in the ocean may not be able to negotiate a catch level that sustains their population, but workers can negotiate a wage that keeps them alive. At least so many economists would have us believe. In the course of this book we will find a number of economic thinkers who did not share this belief. Instead they found it more reasonable to argue that the bargaining power between business and labour was heavily in favour of business. As a result workers might not get the wage a free market should have given them and they might have to work long hours to earn it. This result would add to the number of low-wage workers who did not earn a living wage. Without a living wage these workers might not be able to sustain themselves or their families and there might be a depletion of this resource. To the extent that working long hours to earn a wage diminished the strength and longevity of workers it also hindered the sustainability of the resource.

The usual solution to the tragedy of the commons is to establish private ownership of the resource, giving an owner the incentive to charge a high enough price for using the resource and thus giving users of the resource a further incentive to limit their use. The problem with applying this approach to labour is that we cannot give private ownership of it to anyone. To see this point let us consider slavery. Slave owners have every incentive to take care of their property to ensure that it is sustained. If a business offered to hire 
the slave owners labour force at a rate that would not enable the owners to feed and sustain their slaves, they would be less likely to do so unless they were in a vulnerable condition. Of more importance, they would be negotiating for the entire labour force and in a good condition to know its value. While this may be a case in favour of slavery it is not a persuasive one. For example, slave owners in the South of the US often argued that they treated their slaves better than the manufacturers of the North treated their 'wage slaves'. Whether or not their argument was true, it was not accepted as valid.

Regardless of whether this argument had any merit, in the modern economy we rely on labour markets to set wages. Individual workers in a labour market may be in a better bargaining position than fish in the sea, but we will find economists in this book who did not see their position as strong enough to enable individual workers to secure the wage the market entitled them to. In that case, several of them suggested unions as a way to help workers attain a living wage as being the closest workers could come to privatizing their resource.

\section{CAPABILITY}

There is a second difference between humans and fish. The primary use of a fish is to supply humans with nutrients when we eat them. The capability of a fish to accomplish this objective is largely set by nature, although that capability might be improved by breeding on fish farms. Society has a number of objectives in mind for its human workers. It wants them to be effective workers and effective members of society. In the language of modern economics, this requires that workers develop their human capital and their social capital if they are to participate in life in a meaningful way. In terms of a living wage, this capability approach means workers should be given something more than sufficient nutrition to survive. Sustainability is not an adequate objective for labour in the modern industrialized world. The primary proponent of the capability approach among present-day economists, Amartya Sen, describes it as follows:

The need to take part in the life of a community may induce demand for modern equipment (televisions, videocassette recorders, automobiles and so on) in a country where such facilities are more or less universal (unlike what would be needed in less affluent countries), and this will impose a strain on the relatively poor person in a rich country even when that person is at a much higher level of income compared with people in less opulent countries. Indeed, the paradoxical phenomenon of hunger in rich countries - even the United States - has something to do with the competing demands of these expenses. (Sen, 1999: 89-90) 
Sen's argument implies that a living wage has a capability element to it and we will see that economists in this book found this element to be of importance.

The capability approach means that in looking at wages we also need to take into account whether those wages enable workers to improve their abilities as workers and members of society and to enhance those abilities in their children. At a basic level it includes such capabilities as reading and writing, good health, the right to vote along with the ability to vote wisely, and a capacity for happiness. In the world of the advanced economies, it may include computer literacy and access to the internet, high-priced running shoes for exercise and organic tomatoes for safe nutrition. The capability approach also carries with it the idea that working conditions matter; workers who earn a decent wage under conditions that diminish their capability as workers or as meaningful members of society may not have a living wage. Moreover, it means that the living wage is not a set amount defined by the need to purchase a fixed bundle of goods and services, and this is an idea the economists in this book addressed as well.

In addition, the economists covered in this book had an interest in the impact wages had on the pure economic capability of workers to produce goods and services. Over the last three decades economists have set forth an efficient wage theory which makes a case for the idea that wages have a positive correlation with worker productivity. This theory implies that higher wages will pay for themselves through higher productivity. The higher productivity results from a variety of factors related to higher pay, such as better motivation from workers due to a feeling that they have been treated fairly (Akerloff and Yellin, 1988: 44-9). We will see that this concept has a lineage in the history of economic thought and many of the writers surveyed in this book made it a key element in their discussions of the capability approach.

\section{EXTERNALITY}

An externality is a situation where a person or a business in the pursuit of their individual self-interest creates a side effect that harms or helps someone else. In strictly economic activities, a typical externality would be when a firm produces a product to sell to consumers and in the process imposes a cost or benefit on a person who is not interested in buying the product. The usual example of a negative externality is pollution, where a firm producing tennis balls lets green dye enter into a river making it impossible for persons downstream to swim and thus imposing a cost on them. As long as these costs are not included in the price of tennis balls, the price 
of the tennis balls will not reflect the total resources (cost) of producing tennis balls and will be inefficient.

The idea of externality is not usually applied to work and wages, but we will see that many of the economic thinkers in this book did so in spirit if not in name. Today's free market economists typically think of the wage bargain as being a voluntary exchange that is of mutual benefit to both parties or else it would not take place. In addition, they would think of the wage bargain as being what is called a 'pecuniary externality' (Friedman, 2000: 28). In a labour market, if a worker accepts a job at a lower wage, that person puts pressure on other workers who want the job to reduce their wage demands as well. There is a sense then in which the worker taking the job at a lower wage imposes a cost on other workers. The person hiring the worker has gained from the lower wage, however, so the net costs to society would be zero. A real externality must impose negative costs on society. For this reason, today's economists would be sceptical of finding an externality resulting from low wages.

Thinkers featured in this book, however, found cases where low wages below some standard (they often used the term subsistence wage) imposed costs on others, ranging from the worker's family to society at large. Those cases usually involved consideration of how reduced levels of labour force sustainability or capability due to low wages imposed a cost on society. While those cases will be described in detail in the book, a modern example will show what they meant. Low-wage workers in the US today frequently have no medical insurance, an important feature of a living wage. When they become ill and remain untreated, they suffer directly from the difficulty of the illness, which may reduce their capability; to the extent their lack of medical care prolongs an illness it may spread to others imposing a cost on them. If instead they find treatment in the healthcare system but do not pay for it, someone else must pick up the tab. This is a real cost to society which arguably qualifies as an externality. If low wages lead to workers being malnourished, which adds to their incidence of illness, that too imposes costs on others that can be construed as an externality. From this perspective, one could argue as economists do in cases of an externality that firms that do not pay a living wage are not paying the full cost of the resource they are using. As a result, their incentives are skewed and they produce too much of their product due to their lower costs. This means that resources are being used inefficiently.

Modern economic thinkers have discovered an array of approaches for handling the problem of a negative externality. The basic idea is to give businesses incentives to internalize the externality by making them part of their cost structure. Once the full costs of all the resources used in production become part of a business' operations the business will attain economic 
efficiency. Policies to achieve this internalization include voluntarism where firms recognize the damage they are doing and take care of it themselves, regulation from some government agency that tells businesses what to do, use of taxation to give business the incentive to avoid the tax by taking care of the externality, allowing the persons damaged by the externality to sue the business, following the Coase theorem by having both parties negotiate the allocation of the cost of the externality, and doing nothing in hopes that the market will find a way to solve the problem. These policies have different consequences for economic production, however, and choosing the most efficacious one is important.

The economists surveyed in this book advocated for all of these policies to address the needs of low-wage workers. To be sure, they recognized that wages were a function of workers' skills, the state of technology, the amount of capital, and market conditions of supply and demand and understood that tampering with labour market outcomes had the potential to harm the economy. But they also realized cases where interfering in the market to take care of externalities from work and wages was needed. In the process of analysing those cases they developed early versions of the policies outlined above.

In developing those policies, I will also argue, these economists were partly motivated by an ideal of a moral economy. As will be described in Chapter 2, thinkers such as Plato, Aristotle and Aquinas had argued for a moral economy where decisions were made under a spirit of virtue and mutual assistance. A segment of the economists in this book recognized the value of this moral economy but with the exception of Karl Marx did not believe that it was realizable. Their use of the concepts of sustainability, capability and externality represented their effort to attain the benefits of the moral economy's mutual assistance while harnessing the productive potential of the free market and self-interest. In terms of labour market, they saw that from a social perspective workers had a harder time organizing than did employers, which placed them at a severe disadvantage in negotiations over wages.

In opposition to this moral economy, market economists are motivated by a different ideal, the market economy as represented by the model of perfect competition. To them, this model does a better job of capturing the essential workings of the modern economy than does any version of a moral economy. It is also, they would argue, a more scientific method for investigating economic behaviour. Versions of the moral economy must always reflect the personal preferences of the person writing about them, while an economic model can be investigated and criticized on logical, scientific grounds. Any notion of a living wage must be consistent with the economic model of competition and justified on a scientific basis. We will see that this is a tall order. 


\section{OVERVIEW OF THE BOOK}

Do efforts to improve the standard of living for workers through a living wage result in an improved workforce and a more efficient economy? And if they do, how high should that living wage be? These questions have been a concern of many of the great thinkers in the history of economic thought. This book is a study of how they answered it. Its goal is to bring together the views of these individual thinkers to recount an exchange of ideas regarding the living wage that took place for over two centuries. It will concentrate on a few thinkers, but all of them were influential.

Following this introductory Chapter 1, Chapter 2 will look at the development of the sustainability argument. It will start by describing how Adam Smith built on the ideas of Greek philosophers and Christian moralists to argue that workers should be paid a subsistence wage as equated to a living wage and that the free market could be counted on to produce this outcome in most cases. It will then examine how successive economists built on his ideas and pay special attention to the theory of the role of unions in securing fair wages as elaborated by John Stuart Mill, Alfred Marshall and John Bates Clark, among others. It will then discuss how in the twentieth century market economists eliminated the subsistence wage and the positive features of unions from their thinking. In Chapter 3, the capability approach will be highlighted, starting with Aristotle and Plato on the relationship between income and virtue. It will then analyse the arguments of Adam Smith and John Stuart Mill who argued that a subsistence wage was necessary to enable humans to develop their moral character. Then it will investigate how other economists such as Richard T. Ely and John R. Commons defined capability and made it key to economic study. It will also consider how market economists defined capability in terms of economic production as captured in Gary Becker's theory of human capital. The subject of Chapter 4 will be the theory of externality as applied to labour and wages. The chapter will describe how Adam Smith and Jeremy Bentham saw side effects from self-interested economic decisions but will focus on the ideas of the main advocates of the theory, A.C. Pigou and J.M. Clark, with regard to whether they thought low wages caused a negative externality. This is an idea that market economists found difficult to accept especially after R.H. Coase devised a market approach to handle the externality problem. Throughout these chapters I will offer lessons from the debates among these past thinkers that will inform the current arguments over the need for a living wage and these lessons will be summarized in Chapter 5.

To elaborate on that older debate slightly, what I will argue in this book is that there were a group of economists, let us call them moral economists, 
who supported the idea that low-wage workers should earn a living wage as defined by the standards of the community in which they lived and worked. They often referred to the living wage as a subsistence wage but they never meant that workers should earn a wage that merely enabled them to survive. The subsistence wage to them stood for an amount that was the least workers could make and still feel they were valuable members of the community. The ideal of a community that they held was based on a moral economy rooted in Greek philosophy (Aristotle's household management) and Christian theology (Aquinas's just wage in a moral community).

In opposition to them, there were the market economists. These economists had as their ideal the economic model of perfect competition. This ideal economy gives workers the wages the value-added of their work has earned them, no more and no less. Moreover, these market economists could claim that their interest in this ideal model was purely scientific, as it served the same function for economics as an idealized model of the structure of an atom did for physics. The concept of a subsistence wage (or living wage) did not fit into this idealized model of the market economy, and the market economists did not find it to be a useful analytical concept. Thus in this book we will have a figurative debate between the moral economists and the market economists over the role of a living wage in two versions of an ideal world, the moral economy and the free market economy. Because the market economists have had the last word in the debate I will give more words to the moral economists and will organize the debate around the concepts of sustainability, capability and externality.

By organizing the debate around these concepts I am well aware of the importance of social and historical context in the formation of any economic idea. The worlds that the great economic thinkers highlighted in this book lived in differed from each other's world as well as our own. We cannot compare Adam Smith's views on labour unions with Milton Friedman's because Smith did not know of unions and Friedman at least could read about them. Given that the economists featured in this book lived in a variety of times and places, situating their ideas in a context other than what their predecessors had written would have been a daunting task, although in a few places I have indicated cases of direct social influences. This does not mean that I accept the notion that ideas have a life of their own or that certain economic ideas such as the living wage are universal.

Rather, I hope to show that, at least among economists, ideas such as the living wage change over time and may cause those economists to discard them. The idea of a living wage, for example, has roots in medieval theology regarding the just wage, a concept that fit in with the small community of medieval times. In that community social justice, like criminal justice, 
could be determined on a case-by-case basis. Whether the ideas of social justice and the living wage can be determined on the mass basis of an urbanized, industrial society is an issue the great economists grappled with as that society unfolded during their lives. That issue is the latent focus of this book. 